\title{
The presence of Chinese businesses in the world
}

\begin{abstract}
This article introduces the special issue of the Journal of Evolutionary Studies in Business about the global presence of Chinese businesses and explains some important aspects in order to understand outward Chinese investments. The article also presents the seven special issue articles that provide new insights about the international presence of Chinese companies, in general in the world but with a particular attention paid to investments in Latin American countries.
\end{abstract}

Keywords: Chinese multinationals; International Business; Foreign Direct Investment (FDI); Latin America and the Caribbean (LAC)

It gives great pleasure to present this special issue of the Journal of Evolutionary Studies in Business, which aims to extend the knowledge of Chinese overseas investment, an increasingly visible topic. This scenario triggers many questions and the articles of this special issue offer some answers and explanations. In the following lines I first describe some important characteristics of the Chinese international presence in the world economy, and then introduce the seven articles included in the special issue.

Corresponding author: e-mail: felix.barahona@ub.edu

Received 18 June 2019 - Accepted 28 June 2019

This is an Open Access article distributed under the terms of the Creative Commons Attribution-Non-Commercial-No Derivatives License (http://creativecommons.org/licenses/by-nc-nd/4.0/), which permits non-comercial re-use and distribution, provided the original work is properly cited, and is not altered or transformed in any way. 
The outward investment from developing countries is not a new phenomenon. In the early 1980s, the first studies appeared in the literature explaining the international expansion of a large number of enterprises from emerging economies (Kumar and McLeod 1981; Lall 1983; Wells 1983). However, the existence and importance of Chinese companies in the global arena is fairly recent. This has been particularly evident in recent years since they are able to compete effectively against global rivals in both developed and emerging countries (Child and Rodrigues 2005; Guillen and García-Canal 2009; Luo and Tung 2007; Mathews 2006). Indeed, the growth of Chinese enterprises is clearly evidenced in terms of foreign direct investment (FDI). According to UNCTAD (2019), in the last twelve years (2006-2018), FDI outflows from China have risen dramatically, from US\$ 17,634 million to US\$130,000 million, corresponding currently to $13 \%$ of the global outflows. Consequently, this vigorous growth has translated into an even more spectacular increase of Chinese FDI outward stock, from US\$ 317 billion in 2010 to US\$1,939 billion in 2018 .

However, it also appears that the investment from Chinese multinationals declined for the second consecutive year, due mainly to Chinese government policies to restrain overseas investments, as well as controls exercised by United States and Europe (UNCTAD 2019). It is also true that the Chinese economy recorded in 2018 the lowest economic growth since 1990. Nevertheless, a GDP growth rate of around $6.5 \%$ remains quite high, especially compared with all developed countries.

Despite this overall decline in outward FDI and economic slowdown, it is still clear the ambition of Chinese businesses to continuously grow and climb positions in the global arena. In fact, several Chinese companies have emerged as large multinationals leading their respective sectors. A clear example thereof is the increasing number of Chinese multinationals that appear 
in Fortune's ranking of the world's 500 largest companies: in 2006, only 23 were listed (5\%), growing progressively up to 111 in 2018, representing $22 \%$ of the firms in this ranking (Fortune 2018). Moreover, there are many Chinese companies with great prospects for growth, some of them within huge economic projects by Chinese government such as The Belt and Road Initiative or Made in China 2025. At this point, in order to contextualize the global presence of Chinese firms is important to stress the most prominent elements which characterise this phenomenon.

First, Chinese investments abroad have been traditionally dominated by state-owned enterprises. In fact, before 2004, private firms were not allowed to invest overseas and access to foreign exchange was allowed only to approved state-owned enterprises (Buckley et al. 2008; Ramasamy et al. 2012). Thus, these public firms have been the main driver of the country's FDI, accounting for more than two thirds of total Chinese FDI worldwide (MOFCOM various; Morck et al. 2008). However, the participation FDI by Chinese private firms is growing, thus confirming that several private brands have gained ground in recent years (Ramasamy et al. 2012).

Second, a relevant characteristic of Chinese investments is their accelerated pace of internationalisation (Child and Rodrigues 2005; Mathews 2006; Luo and Tung 2007). Within these operations it can be observed a great ambition to grow on one hand, and the need to obtain some very basic resources to survive on the other. Consequently, one of the main motives of China's FDI is the opportunity to expand their market share in other host economies (Luo and Tung 2007). This is confirmed by various econometric tests conducted on Chinese investment patterns (Buckley et al. 2007; Kolstad and Wiig 2012). The second leading motivation for Chinese investment is strategic asset seeking (Mathews 2006; Luo and Tung 2007). That means 
that Chinese companies are especially interested in acquiring natural resources, technological knowledge and marketing skills in order to improve their competitive advantage in manufactured products (Cui and Jiang 2010; Deng 2009; Rui and Yip 2008; Wang et al. 2012). Due to this, mergers and acquisitions are mainly the entry mode choice used by Chinese enterprises in their international adventures (Deng 2009; Zheng et al. 2016).

Third, Chinese companies also often face specific cross-border problems when entering other markets, particularly developed countries (Barahona et al. 2016; Klossek et al. 2012; Si and Liefner 2014; Wong 2012). Because of the cultural distance between their respective institutional environments, Chinese companies entering developed markets for the first time face what is known as a 'liability of foreignness' (Zaheer 1995), a heavy burden that is not easily shed and which may result in additional costs for those firms that are new to a foreign market. Moreover, Chinese companies' liability of foreignness is even more acute because of country-of-origin effects (Bartlett and Ghoshal 2000; Marano et al. 2017; Moeller et al. 2013). According to Moeller et al. (2013), the country-of-origin information has a significant impact on the quality perception of a product/brand as well as the corporate reputation in the host country. Consumers of developed countries usually expect poorer features from products or services associated with Chinese firms, due to the lack of maturity of the home institutions, which in turn often results in low legal quality requirements. In this regard, Chinese companies are likely to possess an inherited negative image, making it more difficult for these firms to successfully operate in advanced economies (Yu and Liu 2016).

Lastly, another aspect is the progressive change that a good number of Chinese companies are experiencing in their international competitive strategies. That is, they are increasingly opting more for quality of their products and services, something that has come under criticism, the 
lack of quality. Therefore, many Chinese companies, especially, those that operate in sectors of high added value, are abandoning a clear cost leadership strategy for a hybrid approach (Kim et al. 2004; Spanos et al. 2004). This means that they combine moderate prices with good quality. This change has been partly motivated because in developed markets, increasingly important destination of Chinese companies, the price is not everything, that is, quality concerns. Until very recently, China's competitive advantage was marked by low manufacturing costs (Rugman 2009). However, with the progressive increase in the price of inputs and due also to the fact that companies from developed countries are increasingly opting more for automation to close the cost gap with Chinese companies, this way to compete is no longer sustainable. For these reasons, Chinese enterprises have to create a new value based on technological innovation. This strategic change is a real challenge given the prejudices suffered by Chinese brands in developed countries.

This special issue seeks to present new empirical evidence, descriptive analysis and theory development on Chinese businesses in the international arena. In the first article, titled "Chinese companies conquering the world: A descriptive analysis of the rapid rise of Chinese acquisitions", Casanova and Miroux address the study of the global investments of Chinese firms. They put great emphasis on the evolution of mergers and acquisitions (M\&As) but also include greenfield investments and outward foreign direct investments. The study shows that China has become a major global acquirer in recent years, also being increasingly involved in very large transactions. In this sense, the authors found that after the Global Financial Crisis, developed countries were the most important destination, with Europe being the preferred. Surprisingly, Asia (the main recipient of Chinese outward direct investment stock) does not have a significant place in the Chinese companies' acquisitions. Is also remarkable the growing 
interest of Chinese M\&As in Latin America, motivated mainly by currency devaluations. Furthermore, the work shows how the Chinese outbound M\&As has diversified in the last years. Thus, while the energy and materials sectors accounted for the majority of the Chinese investments abroad before the global financial crisis, between 2009 and 2016 many other industries such as industrials, financials, consumer or information technology have become more important.

In "Chinese investments in Latin America: An analysis of host country determinants" Quer, Rienda, and Andreu, examine the role of two host country factors on location decisions by Chinese MNEs in several Latin American countries. Drawing on institutional theory (North 1990), Quer et al., demonstrate that cultural distance and political risk, the two most usual institutional factors considered by scholars when studying location decisions abroad, have different impacts on Chinese decision-making process. On the one hand, the authors find evidence that cultural distance has a conventional negative effect when entering Latin America. That is, Chinese firms tend to invest less in those Latin American countries where there is a greater cultural distance from China. On the other hand, they discover that Chinese companies show a less common behaviour as regards the political risk as an institutional factor. That means that Chinese firms are less risk-averse about political issues. This may be because of the prevalence of Chinese state-owned MNEs and the fact that China maintains good diplomatic relations with many countries that are perceived as riskier by other investors. In fact, the authors found empirical support for this potential explanation trough the analysis of the control variables considered in the study. This research also concludes by highlighting that marketseeking motivation is more important to Chinese MNEs than natural resource-seeking. 
Dalla Costa, Fang Yi, and Althaus, explore "Chinese companies and foreign direct investment in Brazil between 2000 and 2018". They develop a descriptive analysis of the evolution of Chinese investment in Brazil from several databases, thus understanding better this phenomenon. The results show that both Chinese FDI inflows and Chinese firms' presence in Brazil experienced strong growth from 2009, probably due to a significant rise of bilateral trade agreements between the two countries. The analysis also reveals that Chinese investments are mainly concentrated in three sectors: financial activities, insurance and related services; manufacturing industries; and extractive industries and electricity and gas. However, from 2014 on, these investments are gradually diversifying in other industries, as for example in services sectors. Moreover, the authors go in depth into the case of four Chinese MNEs in Brazil such as Sinopec (petroleum sector), Didi Chuxing (technology/startup), State Grid (electric power) and Chery Automobile (auto industry), trying to explain the way they operate in the Latin American country. The authors conclude that given the great differences between both nations, there is still some way to go before Chinese companies achieve an effective adaptation in Brazil. The fourth article, "The Chinese project 'One Belt One Road' toward Latin America and the Caribbean. Economic-financial implications" is also focused on the Chinese investment in the Latin American and Caribbean region. However, this time González focuses on the importance of One Belt One Road (OBOR), one of the top Chinese projects in recent years. Although Latin American and Caribbean countries were not originally included in this large investment project, they will play a very active role within the initiative because this region is one of the main sources of raw materials that China requires to sustain its economic growth. Not only this motive, but Latin American and Caribbean countries represent new opportunities to expand the commercial ambitions of China. The author also notes that the integration between these 
countries as well as the commitment of Latin American governments to change their economic models are vital to ensure the success of this cooperation.

The fifth article of this special issue, "The creation and transfer of entrepreneurship in emerging economies of the world. An approach through large family-owned corporations of China, Mexico and Brazil" by Fernández and Fernández, explains the process of creation and transfer of entrepreneurial spirit in three large family-controlled business groups. More specifically, through a qualitative case study they compare the strategy for the intergenerational transfer of entrepreneurship of Hutchinson Whampoa in China with Grupo Carso (Mexico) and Pao de Açúcar (Brazil). The authors build some theoretical elements such as the role of institutions, the relevance of social networks and dynamic capabilities perspective which support the empirical study. But the importance of networks is the central hypothesis of this research, owing to its great influence on the entrepreneurial process, providing information flows, resources and new business opportunities. Although family and cultural circumstances vary, the study reveals some common practices which favour the successful transfer of entrepreneurship from one generation to another in the analysed companies: creating extensive and valuable networks, promoting the university training in management of family members or recruiting professional managers, among others.

The sixth article, by Palma and Montt Strabucchi, "Chinese business in Latin America and the Caribbean: A historical overview", analyses from a historical perspective the Chinese presence in the region since the arrival of the first Chinese workers in the 1850 s until the Great Depression. Through an extensive literature review and exploring the International Chinese Business Directory of the World of 1913, an important source that registers Chinese businesses in Latin America and the Caribbean, this research presents a very interesting analysis which 
conveys some key messages. First, despite the large Chinese investments in the region are relatively recent, this study demonstrates the existence of Chinese businesses in Latin American countries, particularly in Mexico, Cuba and Peru date from the early twentieth century. The authors explain that it all started as an immigrant movement when Chinese workers came to these countries as slaves. But, as time went on, the Chinese diaspora progressed until part of it become entrepreneurs. Second, and perhaps most important, the article shows that during this period Chinese people and their businesses in Latin America and the Caribbean suffered serious hardships because an important proportion of the local population saw it as a threat to local companies. Therefore, it might resemble with the current perceptions by some people who are concerned about the growing Chinese presence almost everywhere.

Finally, a research note closes this special issue, "Chinese companies in the world" by Nueno, where the author presents a personal evaluation on how the Chinese internationalization should be considered. The author in this research note explains that given the great size of China's economy, few Chinese companies have a global presence. An interesting aspect is the positive message sent towards this recent phenomenon. On the one hand, in contrast to many opinions, the international expansion of Chinese firms are creating several jobs, and will continue to so in both home and host countries. In fact, Nueno claims that this happened in the past when American or European companies emerged as multinationals. On the other hand, Chinese companies expanding their markets are doing exactly the same that American, Japanese and European ones did decades ago and this led to greater competitiveness which benefited many stakeholders around the world. For these reasons this work encourages to contemplate the Chinese firms' internationalisation process as an opportunity and not as a threat.

\section{References}


Barahona, Felix, Fariza Achcaoucaou, and Paloma Miravitlles. 2016. "Mitigating the Isomorphic Conflicts Faced by EMNEs in Southern Europe: The Case of Chinese Subsidiaries in Spain." Journal of Evolutionary Studies in Business 1 (2): 201-234.

Bartlett, Christopher A., and Sumantra Ghoshal. 2000. "Going global: Lessons from late movers." Harvard Business Review 78 (2): 132-142.

Buckley, Peter J., Jeremy Clegg, Adam R. Cross, Xin Liu, Hinrich Voss, and Ping Zheng. 2007. "The determinants of Chinese outward foreign direct investment." Journal of International Business Studies 38:499-518.

Buckley, Peter J., Adam Cross, and Tan Hui. 2008. "Historic and emergent trends in. Chinese Outward Direct Investment.” Management International Review 48 (6): 715-748.

Child, John, and Suzana B. Rodrigues. 2005. "The internationalization of Chinese firms: A case for theoretical extension." Management and Organization Review 1:381-410.

Cui, Lin, and Fuming Jiang. 2010. "Behind ownership decision of Chinese outward FDI: Resources and institutions." Asia Pacific Journal of Management 27:751-774.

Deng, Ping. 2009. "Why do Chinese firms tend to acquire strategic assets in international expansion?" Journal of World Business 44:74-84.

Fortune. 2018. Fortune 5002018 Report. http://fortune.com/global500/2018/. Accessed 17 June 2019.

Guillen, Mauro. F., and Esteban García-Canal. 2009. "The American model of the multinational firm and the 'new' multinationals from emerging economies." Academy of Management Perspectives $23: 23-35$.

Kim, Eonsoo, Dae-il Nam, and John L. Stimpert. 2004. "Testing the applicability of porter's generic strategies in the digital age: a study of Korean cyber malls." Journal of Business Strategies 21:1945.

Klossek, Andreas, Bernd M. Linke, and Michael Nippa. 2012. "Chinese enterprises in Germany: Establishment modes and strategies to mitigate the liability of foreignness." Journal of World Business 47 (1): 35-44.

Kolstad, Ivar, and Arne Wiig. 2012. "What determines Chinese outward FDI?" Journal of World Business 47 (1): 26-34.

Kumar, Krishna, and Maxwell G. McLeod. 1981. Multinationals from Developing Countries. Lexington, MA: Lexington Books.

Lall, Sanjaya. 1983. The New Multinationals: The Spread of Third World Enterprises. New York: John Wiley and Sons.

Luo, Yadong, and Rosalie L. Tung. 2007. "International expansion of emerging market enterprises: A springboard perspective.” Journal of International Business Studies 38:481-498. 
Marano, Valentina, Peter Tashman, and Tatiana Kostova. 2017. "Escaping the iron cage: Liabilities of origin and CSR reporting of emerging market multinational enterprises." Journal of International Business Studies 48 (3): 386-408.

Mathews, John. A. 2006. "Dragon multinationals: New players in 21st century globalization." Asia Pacific Journal of Management 23:5-27.

Moeller, Miriam, Michael Harvey, David Griffith, and Glenn Richey. 2013. "The impact of country-oforigin on the acceptance of foreign subsidiaries in host countries: An examination of the 'liabilityof-foreignness'.” International Business Review 22:89-99.

MOFCOM. Various years Statistical Bulletin of China's Outward Foreign Direct Investment. Beijing: MOFCOM.

http://english.mofcom.gov.cn/article/statistic/foreigninvestment. Accessed 11 June 2019.

Morck, Randall, Bernard Yeung, and Minyuan Y. Zhao. 2008. "Perspectives on China's outward foreign direct investment.” Journal of International Business Studies 39 (3): 337-351.

North, Douglass C. 1990. Institutions, Institutional Change and Economic Performance. Cambridge, UK: Cambridge University Press.

Ramasamy, Bala, Matthew Yeung, and Sylvie Laforet. 2012. "China's outward foreign direct investment: location choice and firm ownership." Journal of World Business 47:17-25.

Rugman, Alan M. 2009. "Theoretical aspects of MNEs from emerging economies." In Emerging Multinationals from Emerging Markets, edited by Ramamurti, R. and Singh, J.V., 42-63. Cambridge: Cambridge University Press.

Rui, Huaichuan, and George S. Yip. 2008. "Foreign acquisitions by Chinese firms: a strategic intent perspective." Journal of World Business 43:213-226.

Si, Yuefang, and Ingo Liefner. 2014. "Cognitive distance and obstacles to subsidiary business success: the experience of Chinese companies in Germany." Tijdschrift voor Economische en Sociale Geografie 105:285-300.

Spanos, Yiannis, George Zaralis, and Spyros Lioukass. 2004. "Strategy and industry effects on profitability: Evidence from Greece.” Strategic Management Journal 25 (2): 139-165.

United Nations Conference on Trade and Development-UNCTAD. 2019. World Investment Report: Special Economic Zones. New York and Geneva: United Nations.

Wang, Chengqi, Junjie Hong, Mario Kafouros, and Agyenim Boateng. 2012. "What drives outward FDI of Chinese firms? Testing the explanatory power of three theoretical frameworks." International Business Review 21 (3): 425-438.

Wells, Louis. 1983. Third World Multinationals: the Rise of Foreign Direct Investment from Developing Countries. Cambridge: The MIT Press. 


\section{Journal of Evolutionary Studies in Business}

Wong, Loong. 2012. “'Liability of foreignness': Chinese investment in Australia.” Transnational Corporations Review 4:46-75.

$\mathrm{Yu}$, Yang, and Yulong Liu. 2016. "Country-of-origin and Social Resistance in Host Countries: The Case of a Chinese firm." Thunderbird International Business Review 58 (6): 1-17.

Zaheer, Srilata. 1995. "Overcoming the Liability of Foreignness." The Academy of Management Journal 38:341-363.

Zheng, Nan, Yingqi Wei, Yabin Zhang, and Jinging Yang. 2016. "In search of strategic assets through cross-border merger and acquisitions: Evidence from Chinese multinational enterprises in developed economies.” International Business Review 25 (1): 177-186.

This is an Open Access article distributed under the terms of the Creative Commons Attribution-Non-Commercial-No Derivatives License (http://creativecommons.org/licenses/by-nc-nd/4.0/), which permits non-comercial re-use and distribution, provided the original work is properly cited, and is not altered or transformed in any way. 